\title{
Effect of Guazuma Leaves (Guazuma ulmifolia) Inclusion as Protein Source on Growing Calves
}

\author{
Amalia Cabrera Núñez, Iliana Del Carmen Daniel Rentería, Miguel Ángel Lammoglia Villagómez, César Enrique \\ Martínez Sánchez, Sara Aída Alarcón Pulido and Rebeca Rojas-Ronquillo \\ School of Biological and Agricultural Science, University of Veracruz, Tuxpan, Veracruz 92860, Mexico
}

\begin{abstract}
The present work was undertaken in a cattle ranch of the north of Puebla state, Mexico. The aim was to incorporate Guazuma leaves (Guazuma ulmifolia) in the diet of growing calves and evaluate its effect on weight gain. Twenty-four Cebu $\times$ Swiss calves (approximately live weight $250 \mathrm{~kg}$ ) were used during all the experimental period $(64 \mathrm{~d})$. They were assigned to a completely randomized design under two treatments ( $n=12$ for each treatment): control $\left(\mathrm{T}_{1}\right)$ consisted of commercial feed based on $15 \%$ crude protein $(\mathrm{CP})+$ cut Taiwan grass and the treatment $\left(\mathrm{T}_{2}\right)$ consisted of a formulated diet containing 14.7\% CP including Guazuma. The composition of the formulated diet consisted of: Guazuma (60\%), rolled corn (12\%), ground sorghum (9\%), oats in grain (7\%), wheat bran (9\%) and vitamins and minerals. The feed was offered twice a day at a rate of $3 \%$ of live weight for $64 \mathrm{~d}$. The mean daily gain for $\mathrm{T}_{1}$ and $\mathrm{T}_{2}$ was $1.15 \mathrm{~g}$ /animal and $1.52 \mathrm{~g}$ /animal, respectively $(p<0.05)$. Results indicate that Guazuma-based supplements resulted in greater productive yield in growing calves.
\end{abstract}

Key words: Calves, Guazuma, suplementation, weight gain.

\section{Introduction}

In most of the tropical and subtropical zones, native grasses are the basic diet for bovine. They are characterized by their low nutritive value; another limitation of grasses is their marked seasonality in terms of fodder production: being abundant during the rainy season and deficient in the dry season. Thus, an urgent need of concentrate incorporation will be justified. This will cause an increase of production costs and make livestock unprofitable [1].

Contrastingly, trees and shrubs have been used for thousands of years for a variety of purposes. Clavero et al. [2] mentioned that direct use, particularly of legumes, to produce fodder is mainly advantageous because of the high protein content of foliage and fruits. Also, the use of tree species in animal feed provides a favorable ambiance in the rumen that induces better fermentation and digestion of low quality fodder [3].

Corresponding author: Rebeca Rojas-Ronquillo, professor, research fields: food biotechnology and dairy science.
Mexico has a large number of important native trees that provide forage for animal feed (Table 1), providing an option for overcoming problems of scarcity and low quality pasture. These trees are of good nutritional quality and, unlike pasture, they continue to produce in periods of seasonal drought [4]. Most of the tree species studied manifest a higher crude protein (CP) content than that of tropical grasses, and in several cases also that of commercial concentrates [5].

Guazuma (Guazuma ulmifolia) is a tree that belongs to the Sterculiaceae family, which is distributed throughout continental America [6]. It typically grows on open sites, river banks and in forests. It grows rapidly, adapting to both arid and humid areas, presenting a height of approximately $20 \mathrm{~m}$. It has a round and extended crown, with a twisted and branched trunk [7]. It is an important tree in silvopastoral systems, as forage and fruits are highly nutritious and appetizing to cattle, leaves have a protein content of $13 \%-17 \%$ and fruits of $7 \%-10 \%$ (Table 2) and are consumed by cattle, horses, sheep, 
Table 1 CP and crude fiber content of arboreal species [5].

\begin{tabular}{|c|c|c|c|}
\hline Species & $\mathrm{DM}(\%)$ & $\mathrm{CP}(\%)$ & CF $(\%)$ \\
\hline Guazuma ulmifolia & 37.6 & 18.6 & 54.3 \\
\hline Cnidoscolus aconitifolius & 16.5 & 42.4 & 86.6 \\
\hline Morus spp. & 28.7 & 23.0 & 79.9 \\
\hline Crescentia alata (flowers) & 17.6 & 11.0 & 77.6 \\
\hline Cnidoscolus chayamansa & 9.3 & 30.8 & 74.8 \\
\hline Verbesina myriocephala & 19.8 & 23.0 & 71.5 \\
\hline Senecio salignus & 26.5 & 23.4 & 71.5 \\
\hline Ficus spp. & 16.9 & 14.4 & 71.3 \\
\hline Verbesina turbacensis & 20.6 & 20.8 & 70.8 \\
\hline Hibiscus rosa-sinenesis & 24.8 & 21.0 & 70.0 \\
\hline Lonchocarpus guatemalensis & 12.4 & 19.5 & 69.4 \\
\hline Brosimum alicastrum & 18.9 & 12.7 & 67.2 \\
\hline Roupala complicata & 26.6 & 42.5 & 66.9 \\
\hline Malvaviscus arboreus & 16.5 & 22.4 & 64.5 \\
\hline Hamelia patens & 15.6 & 17.5 & 61.6 \\
\hline Mimosa platycarpa & 17.8 & 16.0 & 60.0 \\
\hline Gliricidia sepium & 25.1 & 21.6 & 59.2 \\
\hline Libidibia coriaria & 19.0 & 16.0 & 59.0 \\
\hline Trophis racemosa & 20.1 & 12.9 & 56.5 \\
\hline Erythrina berteroana & 22.9 & 24.3 & 55.0 \\
\hline Dendropanax arboreus & 22.0 & 12.1 & 52.7 \\
\hline Cecropia peltata & 19.7 & 19.8 & 51.8 \\
\hline Erythrina poeppigiana & 24.0 & 23.8 & 51.3 \\
\hline Erythrina cocleata & 24.3 & 21.6 & 51.2 \\
\hline Stemmadenia donnel-smithii & 19.1 & 24.4 & 50.6 \\
\hline Polimnia spp. & 17.9 & 22.1 & 45.2 \\
\hline Cordia dentata & 41.0 & 16.0 & 36.0 \\
\hline
\end{tabular}

DM: dry matter; CP: crude protein; CF: crude fiber.

Table 2 Nutritive values of mature leaves and mature fruits of G. ulmifolia [8-10].

\begin{tabular}{llllllllll}
\hline & DM (\%) & CP (\%) & CF (\%) & EE (\%) & CA (\%) & NFE (\%) & NDF (\%) & ADF (\%) & ADL (\%) \\
\hline Mature leaves & 95.1 & 16.1 & 28.1 & 1.3 & 8.6 & 45.9 & 46.1 & 40.0 & 16.5 \\
Mature fruits & 92.5 & 6.8 & 40.3 & 2.1 & 5.5 & 45.4 & 68.7 & 55.4 & 18.7 \\
\hline
\end{tabular}

DM: dry matter; CP: crude protein; CF: crude fiber; EE: ether extract; CA: crude ash; NFE: nitrogen free extract; NDF: neutral detergent fiber; ADF: acid detergent fiber; ADL: acid detergent lignin.

goats and pigs [11].

In Mexico, although it is important in providing milk and meat for human consumption and the conservation of natural resources and the environment, cattle farming is facing a great challenge for increasing its productivity. The main desirable characteristics of trees with multiple uses are found in one or more fodder trees, which have the capacity to sustain repeated pruning and good capacity for regrowth [6]. Therefore, in this research, it is proposed the evaluation of the effect of incorporating $G$. ulmifolia leaf in the diet of growing calves.

\section{Materials and Methods}

This research was developed in the northern area of Puebla state, Mexico, in the municipality of Pantepec, geographically located at latitude $21^{\circ} 16^{\prime} \mathrm{N}$, longitude $98^{\circ} 22^{\prime} \mathrm{W}$ of the meridian, at a height of 160 masl, during the period from September to November 2016.

Twenty four cross breed $(\mathrm{Cebu} \times$ Swiss $)$ calves 
(live weight \pm weighing approximately $250 \mathrm{~kg}$ ) were allocated to two treatments under a completely randomized design $(n=12)$. Control treatment $\left(T_{1}\right)$ was commercial food with $15 \% \mathrm{CP}$. Test treatment $\left(\mathrm{T}_{2}\right)$ consisted of a diet formulated from Guazuma leaves (G. ulmifolia) with 14.7\% CP (Table 3).

The commercial food for $\mathrm{T}_{1}$ consisted of: $28 \%$ ground corn, $28 \%$ ground sorghum, 15\% molasses, $13 \%$ soybean meal, $8 \%$ green alfalfa, $5 \%$ barley, $3 \%$ minerals, vitamin $\mathrm{A}, \mathrm{D} 3$ and $\mathrm{E}$ with $15 \% \mathrm{CP}$ and $70.02 \%$ total digestible nutrients (TND).

An area of 2 ha of Guazuma was identified, it was observed that the trees were sufficient to have an adequate amount of foliage available for the rations; a sample of $400 \mathrm{~g}$ was taken and analyzed in the bromatology laboratory of the Tuxpan campus, Faculty of Biological and Agricultural Sciences, Veracruz University to determine the nutritional contribution, following the method proposed by Van Soest [12] (Table 3). $\mathrm{T}_{2}$ rations were made using this information. The period of adaptation to the use of the Guazuma foliage was $10 \mathrm{~d}$ in grazing under voluntary consumption.

Guazuma leaves were collected manually for the elaboration of $\mathrm{T}_{2}$. Food was produced using a chopper (Kohler, $6.5 \mathrm{hp}, 196 \mathrm{cc}$ ), completely shredding the Guazuma leaf. The $60 \mathrm{~kg}$ of chopped fresh Guazuma leaves were placed on an extended canvas while adding the other ingredients (Table 4), and mixing carefully until homogenous food was obtained. Other ingredients were added in order to have a balanced nutrient supply based on the daily requirements for growing calves proposed by the National Research Council (10\%-18\% CP) [13]: rolled corn, ground sorghum, grain oats, wheat bran; vitamins A, D3 and E; minerals: sodium, zinc, manganese, copper, magnesium, selenium, cobalt, iodine and phosphorus.

Both treatments were prepared daily, being divided into two rations (morning and afternoon), supplied at a rate of $3 \%$ of live weight [13], and offered ad libitum during the $64 \mathrm{~d}$ of the experiment. The food consumption was determined by using the difference between the food initially offered and the rest at the end of each day. The records of feeding were taken daily and twice a month for the calve weight.

Data were processed using the SPSS version 10 statistical package with mean difference analysis, using a $t$-test for independent samples with significance level of $5 \%$.

\section{Results and Discussion}

\subsection{Nutritional Values of the Guazuma Leaf}

The bromatological composition of the Guazuma leaf (Table 4) was $17.12 \%$ of CP. This result is similar to nutritional value reported by Rojas-Hernández [14]

Table 3 Chemical composition of the G. ulmifolia leaves.

\begin{tabular}{ll}
\hline Chemical composition & Content $(\%)$ \\
\hline Protein & 17.12 \\
Dry matter $(\mathrm{DM})$ & 33.88 \\
Crude fiber & 25.79 \\
Crude ash & 6.64 \\
\hline
\end{tabular}

Table 4 Centesimal composition and CP content of food ration based on $G$. ulmifolia leaves $\left(\mathrm{T}_{2}\right)$.

\begin{tabular}{llll}
\hline Ingredient & Weight $(\mathrm{kg})$ & CP (\%) & Total CP (\%) \\
\hline Guazuma & 60 & 17.12 & 10.27 \\
Rolled corn & 12 & 12.00 & 1.44 \\
Ground sorghum & 9 & 12.00 & 1.08 \\
Oats in grain & 7 & 13.00 & 0.91 \\
Wheat bran & 9 & 11.00 & 0.99 \\
Vitamins and minerals & 3 & - & - \\
Total & 100 & & 14.69 \\
\hline
\end{tabular}


Table 5 Nutritional composition of diets based on commercial forage $\left(T_{1}\right)$ and $G$. ulmifolia forage ( $\left.T_{2}\right)$ fed to growing calves.

\begin{tabular}{lll}
\hline Nutritional composition & Commercial forage $\left(\mathrm{T}_{1}\right)$ & Forage based on G. ulmifolia $\left(\mathrm{T}_{2}\right)$ \\
\hline Crude protein (\%) & 15.18 & 14.69 \\
Ether extract (\%) & 19.99 & 8.00 \\
Nitrogen free extract (\%) & 55.93 & 57.68 \\
Crude ash (\%) & 13.33 & 20.00 \\
Crude fiber (\%) & 4.43 & 19.90 \\
TND (\%) & 99.97 & 72.23 \\
\hline
\end{tabular}

Table 6 Weight gain of calves fed with commercial forage $\left(T_{1}\right)$ and forage supplemented with G. ulmifolia $\left(T_{2}\right)$.

\begin{tabular}{lll}
\hline Indicator & $\mathrm{T}_{1}$ & $\mathrm{~T}_{2}$ \\
\hline Initial average weight $(\mathrm{kg})$ & 266.33 & 259.33 \\
Final average weight $(\mathrm{kg})$ & 340.02 & $356.66^{*}$ \\
Average weight gain/animal $(\mathrm{kg})$ & 73.67 & $97.33^{*}$ \\
Weight gain/d $(\mathrm{kg})$ & 1.15 & $1.52^{*}$ \\
Feed consumption/animal/d $(\mathrm{kg})$ & 24.00 & $55.00^{*}$ \\
\hline
\end{tabular}

${ }^{*}$ Results of $t$-test with $p<0.05$.

(16.7\% of CP). This demonstrated that the values obtained for the Guazuma-based supplement with 14.6\% CP complied with the nutritional recommendations indicated by the National Research Council [13] with $10 \%-17 \% \mathrm{CP}$ and $72.23 \%$ of TDN for calves kept in stables of live weight between $200 \mathrm{~kg}$ and $359 \mathrm{~kg}$.

\subsection{Daily Weight Gain of Growing Calves}

The experimental rations used in the present study (Table 5) contained different levels of CP that led to varied response in the calve performance, depending on treatment; this is observed in Table 6 , where $T_{2}$ showed higher values of final average weight, average weight gain, daily weight gain and feed consumption.

The productive performance of animals in the different treatments had significant differences $(p<$ 0.05 ), for $T_{1}$ had $1.15 \mathrm{~kg}$ daily weight gain and 1.52 $\mathrm{kg}$ for $\mathrm{T}_{2}$. These differences were due to the nutritional contribution and the effect that the inclusion of Guazuma as a protein source had on the diet of stabled calves, on the consumption of food and gain in live weight. Notably, the animals that received the commercial supplement with $15 \% \mathrm{CP}$ had a lower weight gain compared to treatments supplemented with vegetable protein, which showed a significantly higher response $(p \leq 0.05)$.
Palatability of food plays a role in ruminant voluntary feed intake. Chemical changes occurring in food drastically alter taste, odor and resistance and consequently decreasing food consumption $[15,16]$. It was shown that voluntary consumption (Table 6) might be the main influence on ruminant weight gain, as greater palatability was observed for food elaborated with Guazuma leaf $(55 \mathrm{~kg})$, evident in the response to the two treatments; $T_{2}$ responded best and greater weight gain was observed compared to $T_{1}$. This effect may have been due to palatability and other compounds present in the food, which suggests that the administration of a diet rich in vegetable protein promotes an increase in the weight of animals that receive this.

Voluntary consumption depends on several factors, including palatability, which is the set of characteristics of the plant that stimulate the animal to consume it [17]. The content of some compounds can increase or reduce the animal's taste for particular forage. A well-known example is that the content of tannins can decrease the palatability of fodder [18], although, at low concentrations, it could improve the use of proteins. G. ulmifolia contains 7\% tannin (Quebracho equivalents) [19], which is a moderate amount of this compound. The consumption of tannin-rich pasture in an amount less than 25\% DM of 
the diet would not represent a nutritional problem [20]. The toxic effect of tannin depends on the plant's concentration and the amount of this in the fodder [21].

Calves may show an innate preference for some foods that may not even have an adequate balance of nutrients [16]. Thus, both palatability and nutritive content must be considered when designing an appropriate diet. It was reported that the calves prefer high energy and high protein foods, which are also considered high palatability. This choice was maintained in the animals even when the ingredients were used in a mixture up to $50 \%$ of the content [22].

The superiority observed in terms of weight gain among calves fed with Guazuma was also influenced by an adequate nutritional contribution derived from food based on the Guazuma leaf, formulated to cover the nutritional requirements of calves at this growth stage [13]. This concurs with that reported by Acero Maldonado [23], who recognizes that daily production per animal is determined by a combination of effects that include availability and quality of the food (energy supplementation-protein), as well as appetite and the genetic potential of the animal.

\section{Conclusions}

The incorporation of the Guazuma leaf to the diet of growing calves improved the intake of the forage; a significant increment was also observed in the daily weight gain. Use of the Guazuma leaf in the diet of the ruminants offers an alternative for cattle production because of the nutritional contribution it makes to the animal's diet. Within strategic supplementation, Guazuma-based food constitutes a strategy for confining ruminants, not only during periods of dry season, but also as a back-up to supply essential nutrients, as it can improve efficiency for utilizing native forage trees during periods of relative abundance. Its easy acquisition makes this a practice that can be easily adopted by producers in the tropical region.

\section{References}

[1] Castro, H. G., Tewolde, A., and Toral, J. N. 2002. "Analysis of Dual Purpose Cattle Production Systems in Chiapas, Mexico." Arch. Latinoam. Prod. Anim. 10 (3): 175-83. (in Spanish)

[2] Clavero, T., Obando, O., and Van Praag, R. 1996. "Effect of Gliricidia sepium Supplementation on Dairy Cows in Production." Pastos y Forrajes 19 (1): 89-91. (in Spanish)

[3] Leng, R. A., Choo, B. S., and Arreaza, C. 1995. "Practical Technologies to Optimize Feed Utilization in Ruminants." Pastos y Forrajes 18 (1): 81-93. (in Spanish)

[4] González, R., Delgado, H., Faria, M., and Morillo, D. 1997. "Evaluation of Pure Cultivations and Associates of Panicum maximum and Centrosema sp. Related with Cut Frecuencies." Arch. Latinoam. Prod. Anim. 5 (1): 63-5. (in Spanish)

[5] Araya, J., Benavides, J., Arias, R., and Ruiz, A. 2000. "Identification and Characterization of Trees and Shrubs with Forage Potential in Puriscal, Costa Rica." In Fodder Trees and Shrubs in Central America, edited by Benevaides, J. E. Turrialba, Costa Rica: CATIE, 31-63. (in Spanish)

[6] Giraldo, L. A. 1998. "Guácimo Tree (Guazuma ulmifolia) Potential as a Forage Component in Silvopastoral Systems." In Agroforestry for Animal Production in Latin America. Rome, Italy: FAO, 295-308. (in Spanish)

[7] The Tropical Agricultural Research and Higher Education Center (CATIE). 1991. Guazuma ulmifolia All-Purpose Tree Species in Central America. Turrialba, Costa Rica: CATIE, 8-9. (in Spanish)

[8] Bressani, R., and Navarrete, D. A. 1959. "Chemical Composition and Digestibility of the Fruit of the Caulote or Guácimo (Guazuma ulmifolia Lam.) and Its Use in Rations for Chicks." Turrialba 9 (1): 12-6. (in Spanish)

[9] De Oca, C. A. G. M., González-Ronquillo, M., Salem, A., Romero-Bernal, J., Pedraza, J. F., and Estrada, J. G. 2011. "Chemical Composition and in Vitro Gas Production of Some Legume Browse Species in Subtropical Areas of Mexico.” Trop. Subtrop. Agroecosyst. 14: 589-95.

[10] Elghandour, M. M., Salem, A. Z., Khusro, A., Cipriano-Salazar, M., Olivares-Pérez, J., Barros-Rodriguez, M. A., and Lugo Coyote, R. 2017. "Assessment of Some Browse Tree Leaves on Gas Production and Sustainable Mitigation of $\mathrm{CH}_{4}$ and $\mathrm{CO}_{2}$ Emissions in Dairy Calves at Different Age." J. Clean. Prod. 162: 1192-9.

[11] Álvarez, A., Savón, L., Duran, F., González, R., Gutiérrez, O., and Mora, P. O. 2012. "Research on Plant Species for Animal Feeding in Two Mountainous 
Regions of the Guantanamo Province." Cuban J. Agr. Sci. 46 (1): $1-5$.

[12] Van Soest, P. J. 1994. Nutritional Ecology of the Ruminant. Ithaca, New York, USA: Cornell University Press, 373.

[13] National Research Council (NRC). 2001. Nutrient Requirements of the Young Calf. 7th ed.. Washington D.C., USA: The National Academies Press, 214-33.

[14] Saul, R. H., Francisca, A. N., Octavio, C. O., Anastasio, G. M., Jaime, O. P., and Trinidad, V. A. M. 2012. "Chemical Composition, in Vitro Digestibility of Foliage Guazuma ulmifolia and Crescentia alata and Its Use in Feeding Lambs.” Pak. J. Nutr. 11 (12): 1139-45.

[15] Cárdenas Medina, J. V., Sandoval Castro, C. A., and Solorio Sánchez, F. J. 2003. "Chemical Composition of Grass and Forage Trees Mixed Silages.” Téc. Ресu. Мéx. 41 (3): 283-94.

[16] Miller-Cushon, E. K., Terré, M., De Vries, T. J., and Bach, A. 2014. "The Effect of Palatability of Protein Source on Dietary Selection in Dairy Calves." J. Dairy Sci. 97 (7): 4444-54.

[17] Mejía Haro, J. 2002. "Voluntary Consumption of Forage by Ruminants in Grazing." A. Univ. 12 (3): 56-63. (in Spanish)
[18] McMahon, L. R., McAllister, T. A., Berg, B. P., Majak, W., Acharya, S. N., Popp, J. D., Coulman, B. E., Wang, Y., and Cheng, K. J. 2000. "A Review of the Effects of Forage Condensed Tannins on Ruminal Fermentation and Bloat in Grazing Cattle." Can. J. Plant Sci. 80 (3): 469-85.

[19] Conklin, N. L. 1994. "Tannin and in Vitro Digestibility of Tropical Browse: Predictive Equations." J. Range Manage. 47: 398-404.

[20] Araujo-Febres, O. 2005. "Factors that Affect Voluntary Consumption in Grazing Cattle under Tropical Conditions." Presented at IX Seminar of Pastures and Forages, 1-12. (in Spanish)

[21] Carmona-Agudelo, J. C. 2007. "Effect of Use of Tree and Shrub Forage on Digestive Dynamics in Bovines." Rev. Lasallista Investig. 4 (1): 40-50. (in Spanish)

[22] Miller-Cushon, E. K., Montoro, C., Ipharraguerre, I. R., and Bach, A. 2014. "Dietary Preference in Dairy Calves for Feed Ingredients High in Energy and Protein." $J$. Dairy Sci. 97 (3): 1634-44.

[23] Acero Maldonado, E. 2005. Food Products and By-products for Ruminants in Confinement. 1st ed.. Ciudad de México, México: Editorial Océano, 23-33. (in Spanish) 